\title{
Investigating Prospective Teachers' Perceived Problem-solving Abilities in Relation to Gender, Major, Place Lived, and Locus of Control
}

\author{
Mustafa Çakır \\ Atatürk Faculty of Education, Marmara University, İstanbul, 34722, Turkey
}

Copyright $(2017$ by authors, all rights reserved. Authors agree that this article remains permanently open access under the terms of the Creative Commons Attribution License 4.0 International License

\begin{abstract}
The purpose of this study is to investigate prospective teachers' perceived personal problem-solving competencies in relation to gender, major, place lived, and internal-external locus of control. The Personal Problem-Solving Inventory and Rotter's Internal-External Locus of Control Scale were used to collect data from freshman teacher candidates $(\mathrm{N}=476)$. Data analysis procedures included descriptive statistics, an independent group t-test, ANOVA, correlational analysis, and hierarchical regression analyses. Findings suggest a significant positive correlation between perceived problem-solving skills and locus of control, place lived, gender, and two subcategories of major. Female participants' problem-solving ability was found to be higher than male participants'; however, male participants' scores indicated stronger internal locus of control than females'. Results show place lived, gender, locus of control, and two categories of major are significant predictors of perceived problem-solving ability $\left(\mathrm{R}^{2}=.125 ; \mathrm{P}<.001\right)$. Implications for teacher education are discussed.
\end{abstract}

Keywords Perceived Problem-solving Skills, Locus of Control, Teacher Education

\section{Introduction}

Teachers' early dropping out of the teaching profession has become a global concern, and the dropout rate is alarmingly high in both developing and industrialized countries worldwide [1]. It is acknowledged that occupational stress is dramatically higher in the teaching profession than most other jobs. Stress is defined as "a negative emotional state occurring in response to events that are perceived as taxing or exceeding a person's resources or ability to cope" [2]. Teachers are the keystone actors in creating an enriching constructive and interactive classroom environment that nourishes the social, emotional, and academic progress of their students. However, the significant amount of work required of them, a lack of support, and the pressure of high stakes exams are among the many sources of stress that teachers must deal with in their everyday professional life. In order to overcome to all the challenges of their profession, teachers are supposed to have a wide range of competences and combine knowledges in multidimensional disciplines such as group management, the learning process, decision-making, and ethics [3]. Additionally, the presence of students in the classroom who have problems of adaptation, difficulty in learning, low motivation, who require special education, who exhibit problematic behavior, and who engage in physical and verbal violence with their classmates [4] is a reason why teachers have to be competent problem solvers as well. Clearly, problem-solving permeates every aspect of the teaching profession [5,6].

The purpose of this study is to investigate the relationship between potential moderating and mediating factors of the personal problem-solving skills of prospective teachers. As potential factors, the effects of gender, major, place lived, and internal-external locus of control variables on personal problem-solving ability are examined. This study primarily focuses on investigating and evaluating prospective teachers' perceived personal problem-solving capabilities and their relationship to gender, major, place lived, and internal-external locus of control. Whether there is variation in internal-external locus of control with respect to gender, place lived, and major variables $w$ is examined.

\subsection{Personal Problem Solving}

Problem solving can be described as acts undertaken to overcome and deal with barriers that individuals face in their lives [7], and problems are defined as the difference between desired results and what is actually faced [8]. Problem-solving skills develop with age [9], and these skills 
may be in varying degrees depending on such factors as intelligence, creativity, endurance, and the frequency of being confronted with problems.

Heppner \& Petersen [10] identified the problems that most often raised by counseling individuals which are vaguely defined and have unspecified operations. Such problems also have vague goals and intangible outcomes. Measuring these personal problems is difficult because the nature of the problems is subjective and the sequences of action for solving them are not always clear. Problem-solving skills have an influence on many psychological characteristics that have a bearing on the state of well-being of individuals. Possessing low problem-solving skills may lead to the emergence of psychological problems [11]. Individuals with high skills in problem solving enjoy lower levels of stress [9]. Such individuals are also more enterprising and adaptive in terms of social communication [12]. Skills in problem solving have an impact on academic performance as well. Individuals with high problem-solving skills enjoy higher levels of academic performance and have less anxiety about taking exams. There is a two-way relationship between academic development and problem solving, where improvement in one leads to development in the other and vice versa [9]. Heppner \& Petersen [10] developed the Problem-Solving Inventory (PSI), which is an instrument that assesses an individual's perceptions of their personal problem-solving behaviors and attitudes.

\subsection{Internal-external Locus of Control}

Locus of control is one of the characteristics that make up the personality of an individual as defined by Rotter $[13,14]$ in the context of social learning theory. It is a construct that represents an individual's perceived control over their environment. Effective problem solvers are, at the same time, individuals with internal locus of control $[15,16,17]$. Locus of control refers to the extent to which an individual believes they have control over events in their life. Here the individual is confronted with two choices: either the individual themselves or everybody/everything but the individual controls all events related to their life [13]. Locus of control, as a construct, refers to the individual's orientation toward reinforcement contingencies that may be internal or external.

Individuals who have internal locus of control attribute outcomes they face to their own actions or traits [18]. Because these individuals hold only themselves responsible for any case of failure, it is possible that they may develop certain psychological problems as a result of excessive burden. According to Rotter [13], these individuals are characterized by high achievement motivation and low outer-directedness. They see success as something static, something waiting there and that they can attain if they are determined enough [19]. Individuals with external locus of control, in contrast, tend to attribute the outcome of their actions or traits to externalities. These individuals most frequently refer to external reasons such as the presence of powerful others, luck or chance, fate, and the conviction that world is too complex to be predicted. Such individuals tend to blame others for outcomes. They hardly establish any link between outcomes they face and their own actions or traits. Various studies reported that internal locus of control is associated with many positive events and developments in an individual's life. In contrast to, relative to those with external locus of control, individuals with internal locus of control demonstrate better academic performance [20,21], self-directed learning levels [22], learning performance [23], self-confidence [24], workplace performance [25], resourcefulness, and more kindness [26].

As mentioned above, there is a positive correlation between internal locus of control and advanced problem-solving skills in individuals [11, 17]. Individuals who think they can alter through their own actions events they face and who associate all outcomes with what they have or have not done [18] are better skilled at solving problems on their own [24]. In contrast, individuals who seek elsewhere the causes of events they face possibly have less developed problem-solving skills due to the conviction that there would be no use in trying a solution they come up with independently [17].

The process of problem solving generally comprises five steps: general orientation, problem definition, the generating of alternatives, decision-making, and evaluation [15]. For an individual to solve a problem, therefore, they must have at the early stage of problem definition the confidence and determination that they can do so $[27,28]$. This self-confidence comes in when the individual concerned thinks that things are under their control. If the individual thinks that problems and their solutions rest with others, then there is no motive for them to take any action to come up with a solution. Locus of control is one of the four dimensions of a structure known as core self-evaluation, along with neuroticism, self-efficacy, and self-esteem [29].

Regarding the relationship between gender and the other variables of the present study, it is reported that internal locus of control is higher in males than females, while external locus of control is higher in females than males [30]. Further, the level of women's problem-solving abilities is higher than for men [25]. Şara [25] reported that the variable place where mostly lived did not correlate with either problem solving or internal-external locus of control.

\subsection{Significance of the Study and Research Questions}

In the current study, prospective teachers' perceived personal problem-solving abilities were examined in relation to their gender, major, place lived, and locus of control. Various studies in the literature have reported on the relations between these variables individually; however, the effect of the four variables together on perceived personal problem-solving skills has not been investigated. Similarly, there is also correlational analysis of locus of control and problem-solving skills, but no clear explanation about which 
predicts the other. The present study tests the hypothesis that internal-external locus of control together with other variables predicts perceived personal problem-solving skills of prospective teachers. It is considered that the findings that are obtained may have guiding value for designing teacher training in problem solving. Knowledge about teachers' level of problem-solving skills and the variables that influence this may help in devising experiences in line with the needs and characteristics of the target group. It is further expected that outcomes will inform the practice for course design by teacher educators.

The purpose of this study was to investigate the roles that gender, major, place lived, and locus of control play in the perceived problem-solving abilities of prospective teachers. Accordingly, the following questions guided the research process:

a) What are the descriptive characteristics of prospective teachers' scores on perceived PSI and locus of control scale?

b) Are there any differences in prospective teachers' perceived problem-solving abilities and locus of control according to their gender, major, and place lived?

c) What relationships, if any, exist between prospective teachers' perceived problem-solving abilities and their gender, major, place lived, and internal-external locus of control?

d) To what extent, if any, is prospective teachers' perceived problem-solving ability influenced by gender, major, place lived, and locus of control?

\section{Methodology}

In this study, a simple descriptive survey approach was utilized in order to conduct an exploratory correlational design study aimed at determining the extent to which gender, place lived, and locus of control as independent variables predict perceived problem-solving skills as a dependent variable.

\subsection{Sample of the Study}

The sample of this study consisted of 476 prospective teachers, who were enrolled in a large urban college of education and were majoring in social studies, Turkish language and literature, English language, Turkish language, history, geography, elementary science, elementary mathematics, chemistry, and biology education programs during academic year 2015-2016 at a large state university in Turkey. Of these participants, 249 were female (52\%) and 227 were male $(48 \%)$. The distribution of participants by their subject of study is as follows: social studies $51(10.7 \%)$; Turkish language and literature 43 (9\%); English language 117 (24.6\%); Turkish language 58 (12.2\%); history 21 (4.4\%); geography 33 (7.8\%); elementary science 53 (11.1\%); elementary mathematics $24(5 \%)$; chemistry 37
$(7.8 \%)$; and biology $39(8.2 \%)$. Characteristics of the participants are presented in Table 1.

Table 1. Sample Characteristics

\begin{tabular}{|c|c|c|}
\hline \multicolumn{2}{|c|}{ Demographical characteristics } & \multirow[t]{2}{*}{$\mathrm{N}(\%)$} \\
\hline Gender & & \\
\hline & Male & $227(47.7)$ \\
\hline & Female & $249(52.3)$ \\
\hline \multicolumn{3}{|l|}{ Major } \\
\hline \multirow{3}{*}{ Social } & Social Studies Education & $51(10.7)$ \\
\hline & History Education & $21(4.4)$ \\
\hline & Geography Education & $33(7.8)$ \\
\hline \multirow{2}{*}{ Turkish } & Turkish Language Ed. & $58(12.2)$ \\
\hline & Turkish Language and Lit. & $43(9)$ \\
\hline \multirow{2}{*}{ Quantitative } & Elementary Science Ed. & $53(11.1)$ \\
\hline & Elementary Math. Ed. & $24(5)$ \\
\hline \multirow{2}{*}{ Science } & Biology Education & $39(8.2)$ \\
\hline & Chemistry Education & $37(7.8)$ \\
\hline English & English Lang. Ed. & $117(24.6)$ \\
\hline \multicolumn{3}{|l|}{ Place Lived } \\
\hline & $1=$ Metropolitan City & $183(38.6)$ \\
\hline & $2=$ City & $112(23.4)$ \\
\hline & $3=$ District & $116(24.5)$ \\
\hline & $4=$ Town $/$ Village & $65(13.5)$ \\
\hline
\end{tabular}

\subsection{Measures}

In this study, the PSI and Rotter's Internal-External Locus of Control Scale (Rotter's I-E Scale) were used to collect data. Additionally, a demographic questionnaire was employed to gather information regarding participants' gender, major, and the place lived mostly during their lives.

\subsubsection{Rotter's Internal-External Locus of Control Scale (Rotter's I-E Scale)}

Rotter's I-E Scale was used [13] to assess the locus of control orientations of prospective teachers. The scale comprises 29 forced-choice items to measure the positions of individuals with respect to the internality/externality of their generalized control expectations. The Turkish version of the scale was adapted by Dağ [31] and consists of 29 pairs of statements, of which 6 are filler items. Dağ [31] reported that the split-half reliability coefficient of the scale ranged from .65 to .79 in various samples. Cronbach's alpha coefficient was .71. For the sample of this study, Cronbach's alpha coefficient was. $78(\mathrm{~N}=476)$. The test-retest reliability of the scale in one-month intervals varied from .49 to .83 . Low scores obtained from the scale indicate internal locus of control, and high scores indicate external locus of control.

\subsubsection{Problem Solving Inventory (PSI)}

The PSI developed by Hepper and Peterson [10] was used 
to measure prospective teachers' perceptions of their problem-solving abilities in everyday life. The instrument is based on 35, 6-point Likert-type items (3 filler items) that assess how individuals perceive themselves as problem solvers. Total scores ranged between 32 and 192. Higher scores indicate that individuals regard themselves as insufficient in terms of their problem-solving skills. A Turkish adaptation study of the PSI was conducted by Şahin, Şahin, and Heppner [32]. They reported Cronbach's alpha coefficient of the Turkish version as.88. Although the original PSI consists of three subscales, namely, problem-solving confidence, approach-avoidance style, and personal control, the Turkish version of the instrument consists of six dimensions, which are impulsive style, reflective style, avoidant style, monitoring, problem-solving confidence, and planfulness [32]. Cronbach's alpha coefficient was $.89(\mathrm{~N}=476)$ for the sample of this study.

\subsection{Data Collection}

The two instruments were administered during regular class hours in the spring semester of academic year 2015-2016. The researcher was present in the class during implementation. Required permissions were acquired, no incentives were offered, and participation was voluntary.

\subsection{Data Analysis}

In order to analyze the data collected, the researcher used a statistical software package (SPSS; Version 20.0). The dependent variable of the survey, which is personal problem-solving skill levels of candidate teachers, was obtained through the PSI. The dependent variables internal-external control locus, gender, place of living, and major were obtained through Rotter's I-E Scale.

Although the PSI has three factors, the analyses in this study are based only on the total score. The assumption of normality of the distributions was tested with the Kolmogorov-Smirnov test. Total scores obtained through both the PSI and Rotter's I-E Scale showed normal distribution $(\mathrm{p}>.05)$. The variable "gender" was turned into a dummy variable for purposes of regression analysis by assigning (1) to male and (0) to female candidate teachers. Because "the place where mostly lived" is considered as a sequential variable, it could be included in the regression analysis without any change. Choices in this variable are coded as $1=$ metropolitan city, $2=$ city, $3=$ district, and $4=$ town/village, and higher numbers denote smaller places of residence. Participating prospective teachers were majoring in 10 different subject areas. Given that certain subject areas had few participants and that there were no significant differences, the subject areas were combined based on similarities in types of university admittance exam scores and participants in the study. As a result of this scheme, participants from biology and chemistry education were combined and labeled as "science," from history, geography, and social studies education were combined and labeled as "social," from elementary science and mathematics education were combined and labeled as "quantitative," and from Turkish language and literature and Turkish were combined and labeled as "Turkish." Participants from "English" education were not combined with any other major. This combination yielded five categories, and each was converted into a dummy variable to include in the regression analysis. Consequently, in order to determine the relationships between these five categories and scores obtained from the PSI, Pearson product-moment correlations were computed. This analysis showed that only the "social" and the "quantitative" category had a significant relationship with scores from the PSI; therefore, only these two categories were included in the regression analysis.

In the data analysis, an independent group t-test, an ANOVA, and a hierarchical regression analysis were used. The independent group t-test was carried out to determine whether there was a difference between female and male students in regard to perceived problem-solving ability and internal-external locus of control. An ANOVA was conducted to determine whether perceived personal problem-solving skills and internal-external locus of control differ among majors and place lived. A hierarchical regression analysis was conducted to test whether and to what extent the independent variables, namely gender, major, place lived, and internal-external locus of control predict perceived personal problem-solving skills of prospective teachers.

\section{Findings}

Results of the data analysis are organized according to the research questions respectively. First, descriptive statistics regarding prospective teachers' perceived problem-solving skills, internal-external locus of control, and demographic variables are presented. In order to respond to the first and second research questions, the results of the independent group t-tests and the ANOVA are shown below in Table 2 . Second, in order to address the third research question, the results of the correlational analysis of variables are presented. Finally, in order to address the fourth research question, the results of the hierarchical regression analysis are presented. The findings shown in Table 2 indicate there is a significant difference between responding male and female prospective teachers in terms of average scores obtained from both the problem-solving skills and the internal-external locus of control scale $(p<.05)$. The findings show that, while female prospective teachers' perceived problem-solving skills are higher than males', the scores of male respondents indicated stronger internal locus of control than those of females. Mean scores obtained with respect to the problem-solving and the internal-external locus of control scale also differ significantly in terms of major $(\mathrm{p}<.05)$. For instance, the problem-solving skills of prospective teachers from the 
"social" category are higher than for others. Further, while prospective teachers majoring in the "social" field have the highest scores on internal locus of control, others studying the "Turkish language" have the lowest. There is also a significant difference with respect to the place lived variable of the respondents in terms of average scores obtained on the scale of perceived problem-solving skills $(\mathrm{p}<.05)$, but there is no significant difference with respect to the same criterion when it comes to the average scores on the internal-external locus of control scale $(\mathrm{p}>.05)$. The findings suggest that the larger the place of mostly lived, the higher the perceived problem-solving ability. Those who have lived mostly in metropolitan cities have the highest perceived problem-solving skills scores.

In order to determine the relationship between the dependent and the independent variables of the study, which was the focus of the third research question, Pearson product-moment correlations were computed. Table 3 shows the results.

The findings indicate a significant positive correlation between perceived problem-solving skills and locus of control $(\mathrm{r}=.21, \mathrm{p}<.01)$, place lived $(\mathrm{r}=.18, \mathrm{p}<.01)$, and gender $(r=.13, p<.01)$. Additionally, perceived problem-solving ability was found to be significantly related to two subcategories of major: "social" $(r=-.19, \mathrm{p}<.01)$ in a negative direction and "quantitative" $(\mathrm{r}=.11, \mathrm{p}<.05)$ in a positive direction. These results confirm that the five independent variables can be included in the hierarchical multiple regression analysis.

In order to respond to the fourth research question, a four-stage hierarchical multiple regression analysis was performed with perceived problem-solving skills as the dependent variable and the factors of place lived, gender, major, and locus of control as the independent variables. Collinearity diagnostics from the regression output indicated no collinearity problem.

Table 2. Descriptive Findings Related to Survey Variables and Results of t-test and ANOVA

\begin{tabular}{|c|c|c|c|c|c|c|c|c|c|}
\hline \multirow{2}{*}{\multicolumn{2}{|c|}{ Variable }} & \multirow[t]{2}{*}{$\mathrm{N}$} & \multirow{2}{*}{$\%$} & \multicolumn{2}{|c|}{ Problem-Solving } & \multirow[t]{2}{*}{$\mathrm{F} / \mathrm{t}-\mathrm{p}$} & \multicolumn{2}{|c|}{$\begin{array}{c}\text { I-E Locus of } \\
\text { Control }\end{array}$} & \multirow[t]{2}{*}{$\mathrm{F} / \mathrm{t}-\mathrm{p}$} \\
\hline & & & & $\bar{X}$ & $\mathrm{Sd}$ & & $\bar{X}$ & $\mathrm{Sd}$ & \\
\hline \multirow{2}{*}{ Gender } & Female & 249 & 52.3 & 91.0 & 13.7 & \multirow{3}{*}{$\begin{array}{l}\mathrm{t}=2.762 \\
\mathrm{p}=.006\end{array}$} & 11.5 & 3.9 & \multirow{3}{*}{$\begin{array}{c}\mathrm{T}=2.908 \\
\mathrm{P}=.004\end{array}$} \\
\hline & Male & 227 & 47.7 & 94.9 & 16.1 & & 10.5 & 3.9 & \\
\hline \multicolumn{2}{|c|}{ Total } & 476 & 100.0 & 92.8 & 14.9 & & 11.0 & 3.9 & \\
\hline \multirow{5}{*}{ Major } & Science-A & 76 & 16.0 & 91.3 & 13.8 & \multirow{6}{*}{$\begin{array}{c}\mathrm{F}=5.487 \\
\mathrm{P}=.000 \\
\\
\text { Scheffe } \\
\mathrm{B}<\mathrm{A}-\mathrm{C}-\mathrm{D}-\mathrm{E}\end{array}$} & 10.8 & 4.3 & \multirow{6}{*}{$\begin{array}{c}\mathrm{F}=4,281 \\
\mathrm{P}=.002 \\
\text { Scheffe } \\
\mathrm{C}<\mathrm{E}\end{array}$} \\
\hline & Social-B & 105 & 22.1 & 87.4 & 14.6 & & 10.2 & 3.5 & \\
\hline & Quantitative-C & 77 & 16.2 & 96.5 & 14.5 & & 10.0 & 3.8 & \\
\hline & English-D & 117 & 24.6 & 93.9 & 14.6 & & 11.7 & 3.8 & \\
\hline & Turkish-E & 101 & 21.2 & 95.3 & 15.7 & & 11.9 & 4.2 & \\
\hline \multicolumn{2}{|c|}{ Total } & 476 & 100.0 & 92.8 & 14.9 & & 11.0 & 3.9 & \\
\hline \multirow{4}{*}{ Place lived } & Metropolitan-A & 183 & 38.6 & 89.9 & 13.8 & \multirow{5}{*}{$\begin{array}{c}\mathrm{F}=4.951 \\
\mathrm{p}=.002\end{array}$} & 10.9 & 3.8 & \multirow{5}{*}{$\begin{array}{c}\mathrm{F}=2.115 \\
\mathrm{p}=.098\end{array}$} \\
\hline & City-B & 112 & 23.4 & 93.1 & 15.6 & & 10.5 & 3.9 & \\
\hline & District- C & 116 & 24.5 & 94.3 & 16.2 & & 11.7 & 4.1 & \\
\hline & Town/Village-D & 65 & 13.5 & 97.8 & 13.3 & & 10.6 & 3.8 & \\
\hline \multicolumn{2}{|c|}{ Total } & 476 & 100.0 & 92.8 & 14.9 & & 11.0 & 3.9 & \\
\hline
\end{tabular}

Table 3. Intercorrelations among Variables

\begin{tabular}{|c|c|c|c|c|c|c|}
\hline & & 1 & 2 & 3 & 4 & 5 \\
\hline \multirow{2}{*}{ Problem Solving } & $\mathbf{r}$ & & & & & \\
\hline & p & & & & & \\
\hline \multirow{2}{*}{ I-E Locus of Control } & $\mathbf{r}$ & $.214^{* *}$ & & & & \\
\hline & p & .000 & & & & \\
\hline \multirow{2}{*}{ Place lived } & $\mathbf{r}$ & $.176^{* *}$ & .019 & & & \\
\hline & $\mathbf{p}$ & .000 & .690 & & & \\
\hline \multirow{2}{*}{ Gender } & $\mathbf{r}$ & $.129^{* *}$ & $-.137^{* *}$ & $.099^{*}$ & & \\
\hline & $\mathbf{p}$ & .006 & .004 & .032 & & \\
\hline \multirow{2}{*}{ Social } & $\mathbf{r}$ & $-.187^{* *}$ & $-.104^{*}$ & -.017 & .035 & \\
\hline & $\mathbf{p}$ & .000 & .028 & .718 & .448 & \\
\hline \multirow{2}{*}{ Quantitative } & $\mathbf{r}$ & $.109^{*}$ & $-.111^{*}$ & -.031 & -.032 & $-.234^{* *}$ \\
\hline & $\mathbf{p}$ & .019 & .019 & .494 & .489 & .000 \\
\hline
\end{tabular}

**. Correlation is significant at the .01 level (2-tailed).

*. Correlation is significant at the .05 level (2-tailed). 
Moreover, assumptions of linearity, homoscedasticity, and normality of residuals were also met. The "place lived" variable life was added to the first stage of the hierarchical multiple regression in order to control the place of residence. Then, the gender variable was included at the second stage, subcategories of major (social-quantitative) were included at the third stage, and, finally, the internal-external locus of control variable was entered at the fourth stage. In the context of responding to the fourth research question, Table 4 shows zero-order correlation and average values. At the first stage of the hierarchical multiple regression analysis, the place lived variable explains $2 \%$ of the variance in problem-solving skills $(\mathrm{R}=.151, \mathrm{R} 2=.023, \Delta \mathrm{R} 2=.021$, $\mathrm{F}=9,999, \mathrm{p}<.01)$. In the second stage, with gender added to the model, the place lived and gender variables together explain $4 \%$ of the variance in problem-solving skills $\left(\mathrm{R}=.190, \mathrm{R}^{2}=.036, \Delta \mathrm{R}^{2}=.032, \mathrm{~F}=7.996, \mathrm{p}<.01\right)$. The major, the only social and quantitative category, is added to the model at the third stage, and this model explains $7 \%$ of the variance in problem-solving skills $\left(\mathrm{R}=.271, \mathrm{R}^{2}=.074\right.$, $\Delta R 2=.065, F=8,434, p<.01)$. Internal-external locus of control was added to the model at the fourth stage, and the final model accounted for $13 \%$ of the variance in prospective teachers' perceived problem-solving skills $(\mathrm{R}=.354$, $\left.\mathrm{R}^{2}=.125, \Delta \mathrm{R}^{2}=.115, \mathrm{~F}=12.097, \mathrm{p}<.01\right)$. Table 5 presents the results of the hierarchical multiple regression analysis.

When the final four-stage model is examined, the place lived variable shows a significant contribution to explaining the variance in perceived problem-solving skills by .02 $(\mathrm{t}=2,780, \mathrm{p}<.01)$, gender by $.02(\mathrm{t}=3.291, \mathrm{p}<.01)$, enrollment in social studies by $.02(\mathrm{t}=2.776, \mathrm{p}<.01)$, numerical by $.01(\mathrm{t}=2.7461, \mathrm{p}<.01)$, and internal-external locus of control by $.05(t=4.985, p<.01)$.

Table 4. Zero-Order Correlation between Variables and Mean Scores

\begin{tabular}{|c|c|c|c|c|c|c|c|c|}
\hline & & 1 & 2 & 3 & 4 & 5 & Mean & Std. Dev. \\
\hline \multirow{2}{*}{ 1- Problem Solving } & $\mathrm{r}$ & & & & & & \multirow{2}{*}{92.77} & \multirow{2}{*}{14.98} \\
\hline & $\mathrm{p}$ & & & & & & & \\
\hline \multirow{2}{*}{ 2-Place lived } & $\mathrm{r}$ & .151 & & & & & \multirow{2}{*}{2.10} & \multirow{2}{*}{1.07} \\
\hline & $\mathrm{p}$ & .001 & & & & & & \\
\hline \multirow{2}{*}{ 3-Gender } & $\mathrm{r}$ & .129 & .097 & & & & \multirow{2}{*}{.48} & \multirow{2}{*}{.50} \\
\hline & $\mathrm{p}$ & .004 & .022 & & & & & \\
\hline \multirow{2}{*}{ 4-Social } & $\mathrm{r}$ & -.180 & -.048 & .029 & & & \multirow{2}{*}{.21} & \multirow{2}{*}{.40} \\
\hline & $\mathrm{p}$ & .000 & .163 & .272 & & & & \\
\hline \multirow{2}{*}{ 5-Quantitative } & $\mathrm{r}$ & .114 & -.011 & -.004 & -.222 & & \multirow{2}{*}{.16} & \multirow{2}{*}{.37} \\
\hline & $\mathrm{p}$ & .009 & .407 & .469 & .000 & & & \\
\hline \multirow{2}{*}{ 6-Rotter's I-E } & $\mathrm{r}$ & .213 & .019 & -.131 & -.094 & -.126 & \multirow{2}{*}{11.05} & \multirow{2}{*}{3.97} \\
\hline & $\mathrm{p}$ & .000 & .347 & .003 & .272 & .004 & & \\
\hline
\end{tabular}

Table 5. Hierarchical Multiple Regression Analysis Examining Effects of Given Variables for Predicting Perceived Problem-Solving Skills

\begin{tabular}{|c|c|c|c|c|c|c|c|c|c|}
\hline Variable & $\beta$ & $\mathrm{t}$ & $\mathrm{p}$ & $\mathrm{sr}^{2}$ & $\mathrm{R}$ & $\mathrm{R}^{2}$ & $\Delta \mathrm{R}^{2}$ & $\mathrm{~F}$ & $\mathrm{p}$ \\
\hline Step 1 & & & & & .151 & .023 & .021 & 9.999 & .002 \\
\hline Place lived & .151 & 3.162 & .002 & .02 & & & & \\
\hline Step2 & & & & & .190 & .036 & .032 & 7.996 & .000 \\
\hline Place lived & .140 & 2.930 & .004 & .02 & & & & & \\
\hline Gender & .116 & 2.425 & .016 & .01 & & & & & \\
\hline Step3 & & & & & .271 & .074 & .065 & 8.434 & .000 \\
\hline Place lived & .133 & 2.824 & .005 & .02 & & & & & \\
\hline Gender & .122 & 2.587 & .010 & .02 & & & & & \\
\hline Social & -.15 & -3.320 & .001 & -.02 & & & & \\
\hline Quantitative & .080 & 1.677 & .094 & .01 & & & & & \\
\hline Step4 & & & & & .354 & .125 & & \\
\hline Place lived & .127 & 2.780 & .006 & .02 & & & & & \\
\hline Gender & .152 & 3.291 & .001 & .02 & & & & & \\
\hline Social & -.13 & -2.776 & .006 & -.02 & & & & & \\
\hline Quantitative & .116 & 2.461 & .014 & .01 & & & & & \\
\hline Rotter & .232 & 4.985 & .000 & .05 & & & & & \\
\hline
\end{tabular}

Note: Standardized regression coefficients reported. $\mathrm{N}=476$. 
In sum, the regression analysis yielded a significant model with $\mathrm{R}^{2}=.125(\mathrm{~F}(5,423)=12.097, \mathrm{p}<.001$. As the place where most of life is spent, or place lived becomes more urbanized, participants' perceived problem-solving skills increase. The problem-solving scores of male students are higher than those of females by 4.546 points, indicating females' lower confidence in their skills. This difference is observed as 3.471 points in the second model and as 3.642 in the third model after gender is added to the models. The difference between the genders increases after other independent variables are added to the model. The problem-solving skills of students enrolled in social studies education are higher than those of others by 4.846 points, while the scores of students enrolled in elementary science and mathematics education are lower than those of others by 4.752 points. Finally, perceived problem-solving skills are positively correlated with scores on internal locus of control. Each unit increase in the internal locus of control score leads to a .878 -point increase in the perceived problem-solving skills scores of prospective teachers.

\section{Discussion}

The present study aimed at answering four research questions: (a) What are the descriptive characteristics of prospective teachers' scores on perceived PSI and locus of control scales? (b) Are there any differences in prospective teachers' perceived problem-solving abilities and locus of control according to their gender, major, and place lived? (c) What relationships, if any, exist between prospective teachers' perceived problem-solving abilities and their gender, major, place lived, and internal-external locus of control? (d) To what extent, if any, is prospective teachers' perceived problem-solving ability influenced by gender, major, place lived, and locus of control?

The results of the study showed that the mean problem-solving score of prospective teachers is 92.8 $(\mathrm{SD}=14.9)$, which is well below the midpoint (112), indicating high perceived competence in problem solving. Their mean score on internal-external locus of control was 11 $(\mathrm{SD}=3.9)$. Their locus of control scores are partly below the midpoint (11.5), which means they are closer to internal locus of control. Previous studies on groups from other universities found 10.7 [33] and 11.2 [25] as mean values for locus of control. Based on this, it can be said that Turkish students across universities are similar with respect to this variable. Berry [34] and Hui [35] reported that there are intercultural variances with respect to locus of control. For example, it was found that locus of control in Eastern and Middle Eastern societies tends to be more external than in Western societies [35]. A more recent study by Stocks, April, and Lynton [36] found the average locus of control score as 13.4 for Chinese students and as 7.3 for South African students. Researchers attribute this difference to the collectivist culture dominant in Asian societies and the individualistic culture in Western societies. Thus, it is noteworthy that the average score in Turkey, as a country located between East and West, is also between these two scores.

In terms of differences between the genders, it was found that, while female participants have significantly higher perceived problem-solving skills than males, locus of control in male students is closer to internal relative to female students. These results are supported by the existing literature $[24,30,37]$. Another outcome is that the problem-solving skills of participants varied by places where they have spent most of their life. Perceived problem-solving skills increase as the place lived is more urbanized. Şara [25] also reported similar findings in a study with prospective teachers.

Results of a hierarchical multiple regression analysis showed that perceived personal problem-solving skills are positively correlated with the level of locus of control, place of living, gender, and two categories of major. These variables are, at the same time, significant predictors of perceived problem-solving skills. The positive correlation between locus of control and problem-solving skills is in line with the findings of earlier studies [12, 15, 16, 17]. Additionally, this relationship is theoretically supported by the fact that both constructs are based on social learning theory and have a strong relationship with self-efficacy [29]. We can infer that having internal locus of control increases the possibility of the individual taking the initiative and starting to solve a problem [28]. The findings of this study also suggest that growing up in a big urbanized environment may have a positive effect on the development of perceived problem-solving skills in an individual.

Prospective teachers' subject area is investigated in this study as well. However, only two categories, social science and quantitative, were found to be significantly related to the perceived problem-solving skills of prospective teachers. While those majoring in social science education areas, social studies, geography, and history have higher perceived problem-solving competence, those majoring in quantitative disciplines, elementary science, and elementary mathematics education have lower confidence in this respect. Interestingly, admission to the quantitative disciplines requires higher achievement on a nationwide college placement exam than do the social sciences. Heppner, Witty \& Dixon [9] stated that there is no relationship between academic success and perceived problem-solving skills. However, there are other studies asserting a significant relationship between the two [38]. The contrast between the findings of the present study and what is reported in the literature suggests that there may be other reasons than academic achievement for this observed difference between majors.

\section{Conclusions and Implications}

Continuing stress not only causes occupational burnout of teachers but also prevents them from engaging in positive 
interactions with their students in order to create a conducive learning environment. According to personality-stress contagion theory [39], worry and stress can spill over from one person to another within a shared social environment such as the school and the classroom. Personal problem-solving skills and locus of control variables are among the assets that help teachers deal with stress. If teachers' personal problem-solving skills are low, their stressful experiences may take a toll, and without any support structure in the workplace or the social environment, they are more likely to use less responsive and more reactive classroom management strategies. Such strategies will not lead to desired educational outcomes, however. Oberle and Schonert-Reichl [40] established a link between classroom teachers' stressful experiences and students' physiological stress levels in the classroom. Anxiety, aggression, isolation, and motivational loss are among the common emotional responses to stress in learning environments. As teaching is a profession that demands constant problem solving, teachers are expected to be competent in this area.

Understanding how prospective teachers perceive their personal problem-solving capabilities in the workplace and in social life can help bring about deeper insight into teacher preparation programs. Examining prospective teachers' beliefs on this issue, as in the present study, is expected to provide a broader definition for potential teacher education programs. This research, which may also be considered as needs analysis, will ensure that the planned course of teacher education is in line with the needs of the target group. Before aiming to enhance the personal problem-solving skills of prospective teachers, it is necessary to identify the perceived level of such skills and its relationship to some other variables. The findings of this study function as an initial prospect for evaluating how to design teacher education settings to support the development of problem-solving abilities. It is important for teachers to have internal locus of control if they are to face educational problems and deal with them properly. An individual's locus of control is not fixed and can be observed at different levels during various stages of life. For example, children take control of their lives and start to refer less to external factors as they grow up $[19,24]$. The locus of control may shift from external to internal through training individuals in intervention [41]. Considering that the locus of control influences problem-solving skills, it would be appropriate to engage prospective teachers in activities to help them develop internal locus of control. Similarly, because the place where most of life has been spent is related to perceived problem-solving skills, it would also be worthwhile to pay special attention to teacher candidates who are from small cities and rural areas.

\section{REFERENCES}

[1] A. M. Aloe, L. C. Amo, M. E. Shanahan, Classroom management self-efficacy and burnout: A multivariate meta-analysis. Educational Psychology Review, Vol.26, No.1, 101-126, 2014.

[2] D. Hockenbury, S. Hockenbury, Psychology ( $3^{\text {rd }}$ Ed.), Worth, New York, 2003.

[3] J. Orgoványi-Gajdos, Teachers' Professional Development on Problem Solving: Theory and Practice for Teachers and Teacher Educators. Springer, 2017

[4] OECD, Creating Effective Teaching and Learning Environments: First Results from TALIS, OECD Publishing, 2009.

[5] R. J. Shavelson, What is the basic teaching skill? Journal of Teacher Education, Vol.24, No. (2), 144-151, 1973.

[6] R. Silverman, W. M. Welty, Teaching with cases. Journal on Excellence in College Teaching, 1, 88-97, 1990.

[7] J. E. Adair, Decision Making and Problem Solving Strategies (Vol. 9), Kogan Page Publishers, 2007.

[8] A. Bingham, Çocuklarda Problem Çözme Yeteneklerinin Geliştirilmesi. (Development of Problem Solving Skills in Children). Milli Eğitim Basımevi, İstanbul. 1998.

[9] P. P. Heppner, T. E. Witty, W. A. Dixon, Problem-solving appraisal: Helping normal people lead better lives. The Counseling Psychologist, Vol.32, No.3, 466-472, 2004.

[10] P. P. Heppner, C. H. Petersen, The development and implications of a personal problem solving inventory. Journal of Counseling Psychology, Vol.29, 66-75, 1982.

[11] P. P. Heppner, C. E. Baker, Applications of the Problem Solving Inventory. Measurement and Evaluation in Counseling and Development, 1997.

[12] P. P. Heppner, B. L. Reeder, L. M. Larson, Cognitive variables associated with personal problem-solving appraisal: Implications for counseling. Journal of Counseling Psychology, Vol.30, No.4, 537, 1983.

[13] J. B. Rotter, Generalized expectancies for internal versus external control of reinforcement. Psychological Monographs: General \& Applied, Vol.80, No.1, 1-28, 1966.

[14] J. B. Rotter, Internal versus external control of reinforcement: A case history of a variable. American Psychologist, Vol.45, No.4, 489, 1990.

[15] T. R. Elliott, F. Godshall, J. R. Shrout, T. E. Witty, Problem-solving appraisal, self-reported study habits, and performance of academically at-risk college students. Journal of Counseling Psychology, Vol.37, No.2, 203, 1990.

[16] P. P. Heppner M. Kampa, L. Brunning, The relationship between problem-solving self-appraisal and indices of physical and psychological health. Cognitive Therapy and Research, Vol.11, 155-168, 1987.

[17] N. Konan, Relationship between locus of control and problem-solving skills of high school administrators. International Journal of Social Sciences and Education, Vol.3, No.3, 786-794, 2013. 
[18] T. W. Ng, K. L. Sorensen, L. T. Eby Locus of control at work: a meta - analysis. Journal of Organizational Behavior, Vol.27, No.8, 1057-1087, 2006.

[19] N. J. Salkind, Encyclopedia of Educational Psychology (Ed.). Sage Publications, 2008.

[20] M. J. Findley, H. M. Cooper, Locus of control and academic achievement: A literature review. Journal of Personality and Social Psychology, Vol.44, No.2, 419, 1983.

[21] A. Tella, A. Tella, A. S. O. Adeniyi, Locus of control, interest in schooling and self-efficacy as predictors of academic achievement among junior secondary school students in Osun State, Nigeria. New Horizons in Education, Vol.59, No.1, 25-37, 2011.

[22] B. Arkan, E. Ü. Avdal, H. Y. Sari, Locus of control and self-directed learning relation on nursing students. International Journal, Vol.9, No.2, 514, 2016.

[23] M. A. Abid, S. Kanwal, M. A. T. Nasir, S. Iqbal, The effect of locus of control on academic performance of the students at tertiary level, International Review of Management and Business Research, Vol.5, No.3, 860, 2016.

[24] M. B. Kormanik, T. S. Rocco, Internal versus external control of reinforcement: A review of the locus of control construct. Human Resource Development Review, Vol.8, No.4, 463-483, 2009.

[25] P. Şara, Sınıf öğretmeni adaylarını öğrenme ve ders çalıșma stratejileri, problem çözme becerileri ve denetim odağ düzeylerinin çeşitli değişkenler açısından incelenmesi. (Unpublished doctoral thesis). University of Dokuz Eylül, Izmir, Turkey, 2012.

[26] H. N. Basim, H. Şeșen, Kontrol odağının çalışanların nezaket ve yardım etme davranışlarına etkisi: kamu sektöründe bir araștırma. Selçuk Üniversitesi Sosyal Bilimler Enstitüsü Dergisi, No.16, 159-168, 2006.

[27] S. Avc1, T. Akinci, A. Bakioglu, Using real life problems for developing prospective teachers' classroom management skills. Çukurova University Faculty of Education Journal, Vol.41, No.2, 18, 2012.

[28] J. E. Pretz, A. J. Naples R. J. Sternberg, Recognition, defining and representing problems, J. E. Davidson, R. J. Sternberg, (Eds.) The Psychology of Problem Solving, (3-30) New York, Cambridge University Press, 2003.

[29] T. A. Judge, E. A. Locke, C. C. Durham, The dispositional causes of job satisfaction: A core evaluations approach. Research in Organizational Behavior, Vol.19, 151-188.
[30] N. B. Serin, O. Serin, F. S. Sahin, Factors affecting the locus of control of the university students. Procedia-Social and Behavioral Sciences, Vol.2, No.2, 449-452, 2010.

[31] İ. Dağ, Rotter'in İç-D1ş Kontrol Odağı Ölçeği (RİDKOÖ)'nin üniversite öğrencileri için güvenirliği ve geçerliği. Psikoloji Dergisi, Vol.7, No.26, 10-16, 1991.

[32] N. Şahin, N. H. Şahin, P. P. Heppner, Psychometric properties of the problem solving inventory in a group of Turkish university students. Cognitive Therapy and Research, Vol.17, No.4, 379-396, 1993.

[33] S. G. Tekeli, Lise son sınıf öğrencileri ile üniversite öğrencileri arasında bir karşılaştırma: akademik benlik yeterliği, denetim odağı, stresle başa çıkma ve problem çözme becerisi. (Unpublished doctoral thesis). University of Ankara, Ankara, Turkey, 2010.

[34] J. W. Berry, Cross-cultural Psychology: Research and Applications, Cambridge University Press, 2002.

[35] C. C. H. Hui, Locus of control: A review of cross-cultural research. International Journal of Intercultural Relations, Vol.6, No.3, 301-323, 1982.

[36] A. Stocks, K. A. April N. Lynton, Locus of control and subjective well-being-a cross-cultural study. Problems and Perspectives in Management, Vol.10, No.1, 17-25, 2012.

[37] A. C. Sherman, G. E. Higgs, R. L. Williams, Gender differences in the locus of control construct. Psychology \& Health, Vol.12, 239-248, 1997.

[38] R. Derin, İlköğretim 8. sınıf öğrencilerinin problem çözme becerileri ve denetim odağı düzeyleri ile akademik başarıları arasındaki ilişki. (Unpublished master's thesis). University of Dokuz Eylül, Izmir, Turkey, 2006.

[39] M. A. Milkie, C. H. Warner, Classroom learning environments and the mental health of first grade children. Journal of Health and Social Behavior, Vol.52, No.1, 4-22, 2011.

[40] E. Oberle, K. A. Schonert-Reichl, Stress contagion in the classroom? The link between classroom teacher burnout and morning cortisol in elementary school students. Social Science \& Medicine, Vol.159, 30-37, 2016.

[41] T. Manger, O. J. Eikeland, A. Asbjornsen, Effects of social-cognitive training on students' locus of control. School Psychology International, Vol.23, No.3, 342-354, 2002 